\title{
PENERAPAN MODEL PEMBELAJARAN PROBLEM POSING UNTUK MENINGKATKAN DAYA KRITIS DAN KREATIVITAS SISWA SMP
}

\author{
Sungkono, Asih Ryanti, dan Tesa Lutfi Yanasari \\ Jurusan Pendidikan Bahasa Indonesia, Fakultas Keguruan dan Ilmu Pendidikan, \\ Universitas Borneo Tarakan \\ E-mail : asihriyanti17@gmail.com
}

\begin{abstract}
ABSTRAK
Kegiatan Porgram Kemitraan bagi masyarakat ini bertujuan menyelidiki dampak sosialisasi dan pendampingan penerapan model pembelajaran Problem Posing bagi guru SMP di Tarakan. Melibatkan 15 guru MTs Al-Fattah Hidayatulloh Tarakan Kalimantan Utara dan menggunakan Insrumen angket untuk pengumpulan datanya. Data diolah secara kualitatif dan kuantitatif. Hasil dari kegiatan bahwa para guru di MTs Al-Fattah Hidayatulloh Karungan Tarakan Kalimantan Utara belum menerapkan model pembelajaran karena alasan minimnya sarana, kurang persiapan mengajar, dan tidak memahami sintak dalam model pembelajaran. Salah satu solusi yang tepat ialah melakukan kegiatan sosialisasi dan pendampingan dalam penerapan model pembelajaran Problem posing. Setelah diadakannya kegiatan ditemukan dampak bagi guru dan siswa. Hasil yang didapatkan adalah (1) memberikan pemahaman dalam penerapan model pembelajan Problem Posing, (2) sintak model pembelajaran Problem Posing dapat diapahami dan mudah diingat, (3) model pembelajaran Problem Posing dapat meningkatkan daya kritis dan kerativitas siswa, (4) para guru antusias melakukan penelitian tentang implementasi model pembelajaran Problem Posing, dan (6) para siswa antusias mengikuti pembelajaran dengan model pembelajaran Problem Posing. Hal ini terlihat sebanyak $85 \%$ guru menggunakan metode ceramah dan metode diskusi $15 \%$ sebelum dilakukan sosialisasi. Setelah dilakukan sosialsiasi meningkat banyaknya guru yan menggunakan model Problem posing 96\% dan menggunakan metode ceramah $4 \%$. Ada peningkatan $93 \%$ guru yang paham sintak model pembelajaran, karena sebelum dilakukan sosialisasi guru yang tidak paham sintak sebanyak $94 \%$ dan $6 \%$ memahami sintak model pembelajaran. Adapun prsentase guru yang paham sintak model pembelajaran Problem Posing meningkat sebanyak 99\% dan $1 \%$ yang tidak memahaminya setalah pelaksanaan kegiatan karena masih dalam proses pemantapan pembuatan perangkat pembelajaan.
\end{abstract}

Kata Kunci: guru, model pembelajaran Problem Posing, berpikir kritis, kerativitas

\section{PENDAHULUAN}

Masa pandemi covid-19 menjadikan dunia pendidikan berubah dalam pelaksanaannya, termasuk dalam pembelajaran. Banyak dilakukan oleh guru ketika masuk kelas, yaitu tatap muka dan mengajarkan atau menyampaikan materi dengan ceramah serta pemberian tugas-tugas yang harus dikerjakan siswa. Kini kegiatan pembelajaran berubah harus secara online. Ini menjadi sebuah tantangan bagi guru dan siswa untuk tetap dapat menyampaikan materi dengan baik dan 
menghasilkan siswa mencapai hasil belajar yang optimal. Oleh sebab itu guru harus bisa menjadikan siswa mampu berpikir kritis dan memiliki kerativitas. Guru bukan hanya sekedar menstransfer ilmu pengetahuan, namun harus dapat mengintegrasikan pengalaman dan pengetahuan siswa terhadap materi yang diterima di sekolah dengan pengalaman atau pengetahuan yang dimilikinya. Siswa sebagai anggota masyarakat harus memiliki kepekaan sosial yang bisa nantinya untuk memecahkan masalahmasalah yang ada dengan daya pikirnya.

Dalam arti luas pendidikan merupakan sebuah proses yang berkaitan dengan usaha mengembangkan diri seseorang.(Ikhwani, Budiman, \& Rasyidan, 2015). Guru harus memiliki ide untuk berinovasi yaitu salah satunya dengan menggunakan atau mengembanngkan model pembelajaran untuk meningkakan daya kritis dan kreativitas siswa. Pengembangan model pembelajarn belum banyak guru mampu dan bersedia melkaukaknya. Kurangnya pemahaman terhadanp pentingnya suatu model pembelajaran dan kurangnya sosialisasi danri pihak sekolah menjaddikan guru di kelas hanya menyampaikan materri dengan ceramah. Inilah yang menjadi keprihatinan. Oleh karena itu salah satu langkah untuk meningkatkan pemhaman guru terhadap pelaksanaan pembelajaran maka dilakukan sosialisasi model pembelajaran bagi guru-guru. Berbagai model pembelajaran yang ada, salah satunya adalah model pembelajaran model Problem Posing, yang dilakukan siswa secara mandiri dan berpikir serta mengembangkan kerativitas siswa tanpa terkekang dengan apa yang hanya didapatkan di sekolah.

Siswa sangat penting untuk dibekali dengan keterampilan berpikir kritis dan kreatif agar dapat menjalankan peran dan tanggung jawabnya secara efektif di sekolah, keluarga, dan masyarakat. Berpikir kritis dapat pula membantu seseorang dalam menerapkan tingkat pertimbangan profesional tertentu yang diperlukan (ÇALIK, ÇELİK, and SÖNMEZ 2018). ini akan memperluas pemahaman seseorang mengenai analisis resiko dan area dengan tingkat kompleksitas yang tinggi dalam keterampilan apapun. Keterampilan berpikir kritis yang diterapkan dalam berbagai situasi penting untuk hidup seseorang terhadap apapun yang dikerjakan. Berpikir Kritis adalah proses mental dalam menganalisis atau mengevaluasi 
informasi (Latif et al. 2019). Tujuan dari pemikiran kritis adalah untuk mempromosikan pemikiran independen, otonomi pribadi dan pertimbangan yang logis. Ini melibatkan dua dimensi yakni bernalar dengan baik dan disposis untuk melakukannya. Pendekatan berpikir kritis untuk melatih siswa siap memasuki pasar profesional. Berpikir kritis juga dikaitkan dengan tujuannya yaitu mengeksplorasi suatu situasi, fenomena, pertanyaan, atau masalah untuk sampai pada hipotesis atau kesimpulan yang mengintegrasikan semua informasi yang tersedia dan itu karena dapat dibenarkan secara meyakinkan.

Adan enam keterampilan berpikir kritis disampaikan (Facione, 1990) yaitu interpretasi, analisis, evaluasi, interfensi, penjelasan, dan pengaturan diri. Makna dekoding dan mengklarifikasi makna (interpetasi), memeriksa ide, mengidentifikasi argumen dan menganalisis argumen (analisis), menilai arguen (evaluasi), mempertanyakan bukti, menduga alterrnatif dan menggambar kesimpulan (interferensi), menyatukan hasil, membenarkan prosedur dan menyajikan argument (penjelasan) dan pemeriksaaan serta koreksi diri (self- regulation). Siswa selain harus memiliki daya kritis yang baik juga harus memilki kreativitas yang menarik. Bukan hanya siswa yang harus memilki kemampuan keduanya, tetapi guru harus dapat menumbuhkembangkan keduanya sehingga nantinya siswa menjadi insan yang berguna bagi dunia kerja, keluarga, dan masyarakat. Upaya mengembangkan kerativitas keilmuan perlu dilakukan melalui pegembangan kemampuan kreativitas ilmiah. Pemikiran kritis dan kreatif mempunyai peran sentral dalam pendidikan dan merupakan tujuan utama dari pembelajaran. Keterampilan berpikir kreatif dan kreatif termasuk dalam kompetensi kognitif. Kreativitas adalah semua pemikiran divergen, pemikiran produktif, heuristik berpikir inventif dan berpikir lateral. Kreativitas ilmiah dapat berupa menciptakan, mememukan, membalikkan, membayangkan, mengandaikan dan berhipotesis. Indikator kreativitas ilmiah dapat diimplementasikan dalam pembelajaran proses dengan menggunakan model pembelajaran yang menuntut keaktifan siswa.

Guru berperan dalam mengemabngjan potensi yang dimilki siswa (Rendi, Jainal Arifin, Firda Herlina, Sobar Ihsan and dan Gusti 
Rusdy Furqon Syahrillah 2020). Pembelajaran yang baik bukan hanya sekadar guru menyampaikan materi dan siswa mendengarkan ceramh guru, tetapi keaktifan siswa menjadi salah satu ukuran keberhasilan proses pembelajaran. Dalam setting Problem Posing, melibatkan siswa. Siswa membutuhkan untuk menghasilkan masalah baru atau merumuskan ulang masalah yang ada (Christidanmayani and Kristanto 2020). Kegiatan melibatkan siswa dalam merumuskan masalah dianggap sebagai upaya untuk meningkatkan pembelajaran siswa secara aktif (Cai and Jiang 2017). Hal itu bisa dilakukan guru dengan meggunakan model pembelajaran Problem Posing. Model tersebut yang dapat meningkatkan prestasi belajar siswa, penalaran, berpikir kritis, kreatif, keterampilan berkomunikasi, dan meningkatkan motivasi siswa (Hwang, Jiang, \& Silbar, 2015). Hal ini berpotensi meningkatkan hasil belajar siswa dan motivasi. Hobri (2008) mendefinisikan Problem Posing sebagai (a) rumusan pertanyaan sederhana atau rumusan ulang masalah yang ada dengan beberapa perubahan sehingga lebih sederhana dan dapat dikuasai; (b) rumusan soal yang berkaitan dengan kondisi soal yang telah diselesaikan untuk mencari alternatif pemecahannya; (c) rumusan masalah dari informasi atau situasi yang tersedia, baik dilakukan sebelum, kapan, atau setelah penyelesaian masalah. Oleh karena itu model ini menjadi suatu inovasi ketika digunakan dalam pelaksanaan pembelajaran, yang tentu disesuaikan dengan materi ajar, tujuan pembelajaran, kondisi siswa, dan hal yang menjadi faktor penentu keberhasilan belajar siswa.

Penelitian yang serupa pernah dilakukan (Christidamayani and Kristanto 2020) berjudul The Effects of Problem Posing Model on Students. Learning Achievment and Motivation. Penelitian ini dilakukan dengan eksperimen dan dihasilkan adanya dampak penggunaan model Problem Posing dapat meningkatkan motvasi belajar matematika siswa. Persamaannya adalah sama-sama menggunakan model pembelajaran Problem Posing namun ada peredaan dalam penerapannya yakni digunakan pada mata pelajaran dan kali ini melakukan sosialisasi bagi guru SMP. Hasil penelitiannya menunjukkan Problem Posing dapat digunakan dalam pembelajaran matematika dan meningkatkan hasil belajar matematika. 
Penelitian juga dilakukan oleh Kartika Irawati (2014) mengenai Pengaruh Model Problem Posing serta Kemampuan Awal terhadap Hasil Belajar Siswa. Persamaan dengan penelitian ini yaitu menggunakan model pembelajaran Problem Posing, tetapi peneiltian sebelumnya melihat pengaruhnya terhadap kemampuan awal siswa, sementara ini untuk melihat dampak penerapan model pembelajaran Problem Posing dalam meningkatkan daya kritis dan kreativitas siswa. Pada penelitian itu menggunakan rancangan eksperiman, dan hasilnya menunjukkan bahwa Problem Posing lebih efektif meningkatkan hasil belajar siswa dibandingkan Problem Solving. Terbukti dengan tingginya kemampuan hasil belajar siswa ketika pembelajaran dengan Problem Posing.

Kendati demikian masih banyak guru yang mengabaikan faktor-faktor penunjang keberhasilan siswa. Bahkan guru Sekolah Menengah Pertama (SMP) kurang memahami pengertian, kelebihan, dan penggunaan model pembelajaran. Untuk itu dilakukan pendekatan kepada guru-guru agar ke depannya menjadi lebih baik dan berinovasi dalam melaksanakan kegiatan belajar mengajar, sehingga dilakukanlah
PKM yaitu "sosialisasi penerapan model pembelajran Problem Posing untuk meningkatkan daya kritis dan kreativitas siswa di SMP".

\section{METODE PELAKSANAAN}

Kegiatan Porgram Kemitraan bagi Masyarakat ini bertujuan menyelidiki dampak sosialisasi dan pendampingan implementasi model pembelajaran Problem Posing terhadap kesiapan guru SMP dalam mengimplementasikan model tersebut. Selain itu untuk menggambarkan perubahan yang telah terjadi menyangkut pengetahuan, keterampilan dan sikap dalam penerapan model pembelajaran sebaagi dampak dari kegiatan sosialisasi dan pendampingan implementasi model pembelajaran Problem Posing.

Kegiatan ini melibatkan 15 guru partisipan di MTs Al-Fattah Hidayatullah Karungan Kalimantan Utara. Teknik pengumpulan data menggunakan angket mengenai model pebelajaran yang selama ini digunakan dan sedang digunakan oleh guru. Angket kedua untuk menggali informasi mengenai pengetahuan, keterampilan, dan sikap guru sebelum dan sesudah mengikuti sosialisasi dan pendampingan 
yang telah dilaksanakan. Analisis data dilakukan dengan kuantitatif dan kualitatif.

\section{HASIL DAN PEMBAHASAN}

Kegiatan ini dilakukan melibatkan sekolah tingkat SMP, yakni MTs Al-Fattah Hidayatulloh Karungan Tarakan Kalimantan Utara di mana sekolah ini sebagai sekolah yang berbasis agama islam. Siswa laki-laki dan siswa perempuan dipisahkan (tidak satu kelas) dan pada gedung yang berbeda meskipun dipimpin oleh kepala sekolah yang sama. Siswa bukan hanya mempelajari ilmu umum tetapi juga mempelajari ilmu agama. Di sekolah tersebut sarana prasana pembelajaran masih kurang. Sekolah ini berada tidak di wilayah perkotaan. Adanya kegiatan sosialisasi bertujuan untuk membantu para guru mengembangkan potensi dirinya dalam hal meningkatkan kualitas diri dan kualitas siswa. Terbatasnya literatur dalam menjawab apakah model pembelajaran Problem Posing efektif dalam meningkatkan daya kritis dan kreatif siswa maka kegiatan ini menunjukkan menjadi solusi dari permasalahan guru dan siswa. Berikut kegiatan PKM secara yang dialkukan secara online melalui zoom meeting.

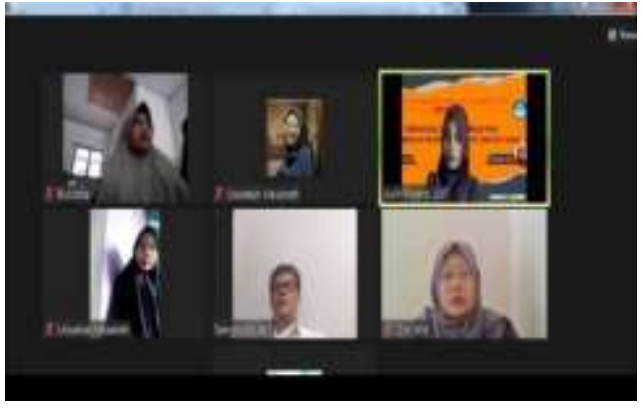

Gambar 1. Narasumber menyampaikan

Sosialisasi kepada guru di MTs AlFattah Hidayatullah

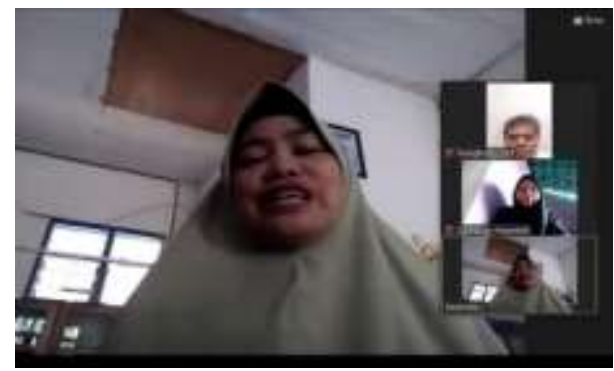

Gambar 2. Salah satu guru sedang mengemukakan pertanyaan pada kegiatan sosialisasi

Berdasarkan hasil yang diperoleh melalui angket didapatkan mengenai informasi penggunaan model, metode, strategi pembelajaran yang pernah digunakan dan sedang digunakan dalam pelaksaan kegiatan belajar mengajar. Diperoleh hasilnya yaitu penggunaan model ceramah $85 \%$ dan metode diskusi $15 \%$. Berikut gambar presentasenya metode pembelajaran sebelum sosialisasi dilakukan. 


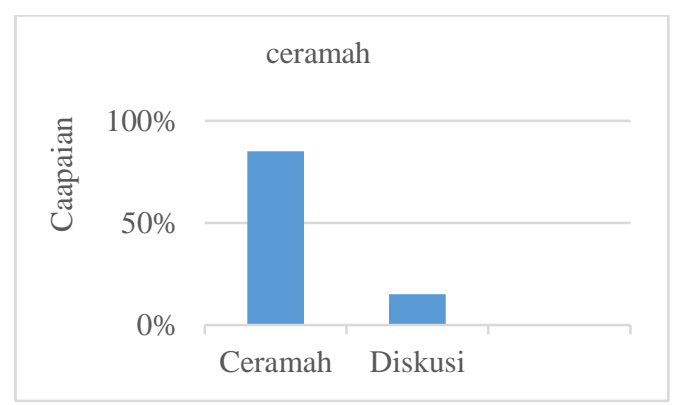

Gambar 4. Penggunaan

Metode Pembelajaran Sebelum

Dilakukan Sosialisasi

Berdasarkan tabel di atas terlihat bahwa guru menggunakan dua metode pembelajaran untuk mengajarkan materi kepada siswa. Guru lebih banyak menggunakan metode ceramah yaitu sebanyak $85 \%$ dan metode diskusi $15 \%$. Ketika guru masuk kelas maka lebih banyak menyampaikan materi menggunakan lisan (bahasa verbal) yang didukung oleh buku sekolah. Diskusi dilakukan hanya pada saat siswa diminta untuk mengerjakan tugas di kelas dan ini hanya dilakukan tidak lebih dari lima kali dalam satu semester.

Angket juga dibagikan kepada guru-guru untuk mengetahui tingkat pengetahuan terhadap model pembelajaran. Hasilnya diketahui bahwa guru kurang memahami sintaks model pembelajaran sebelum dilakukan sosialisasi. Ittulah sebabnya guru mengungkapkan tidak menggunakan suatu model pembelajaran dalam proses penyampaian materi ajar. Berikut gambar pemahaman guru terhadap sintaks model pembelajaran sebelum sosialisasi.

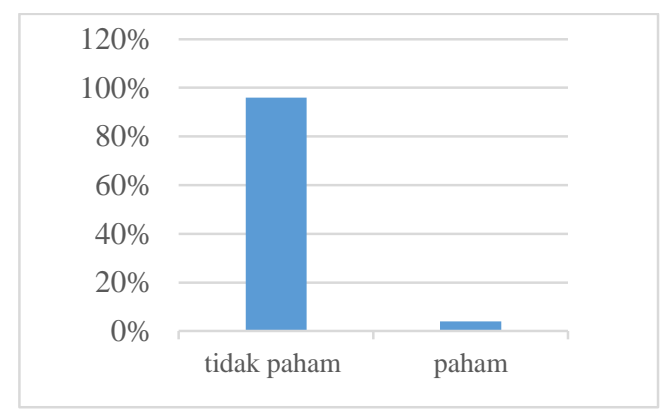

\section{Gambar 5. Pemahaman Guru \\ terhadap Sintaks Model \\ Pembelajaran Sebelum Sosialisasi}

Berdasarkan gambar 2 persentase tidak paham mengenai sintak model pembelajaran lebih banyak dari pada yang kategori yang paham. Hal ini menunjukkan bahwa guru di MTs AlFattah Hidayatulloh masih perlu meningkatkan dan mengembangkan kompetensi diri untuk menyiapkan pelaksanaan kegiatan belajar mengajar. Terlihat ada $96 \%$ guru yang tidak paham sintak model pembelajaran. Artinya hanya ada $4 \%$ yang paham sintak model pembelajaran. Ketidakpahaman guru terhadap model pembelajaran diakui bahwa selama ini merasa bahwa sintak setiap model pembelajaran sulit dimengerti dan ada banyak yang harus lebih dipersiapkan untuk mempersiapkan siswa menghadapi tes atau ujian akhir semester. Guru khawatir 
apabila materi tidak tersampaikan dengan tuntas. Adaya kesulitan para guru dalam memahami dan motivasi untuk menggunakan model pembelajaran ini memerlukan solusi yaitu berupa adanya alternatif model pembelajaran yang efektif dapat meningkatkan daya pikir dan kerativitas siswa. Pemilihan model pembelarajaran harus disesuaikan dengan materi pembelajaran, keadaan siswa, lingkungan, dan tujuan pembelajaran. Melalui sosialisasi dan pendampingan ini menjadi antusias dan merespon dengan baik terhadap penerapan model pembelajaran Problem Posing dalam pembelajaran.

Dampak kegiatan sosialisasi model pembelajaran yang dilaksanakan berpengaruh bagi guru dan siswa dalam pengetahuan, keterampilan, dan afektifnya. Aspek yang dapat dikembangkan melalui model pembelajaran Problem Posing yaitu berpikir kritis, pemecahan masalah, kerativitas, kemampuan komunikatif, dan saling menghargai.

Dari hasil angket didapatkan guru menggunakan Problem Posing sebanyak 94\% dan belum menggunakan model tersebut sebanyak 6\%. Presentasi $6 \%$ dimana guru ini masih menggunakan ceramah serta dalam tahap pembuatan perencanaan pembelajaran lebih matang dan mencari dan membuat media yang sesuai dengan pembelajaran dikarenakan sekolah tersebut masih kurang sarana prasarana pembelajarannya. Berikut gambar penggunaan metode pembelajaran setelah dilakukan sosialisasi.

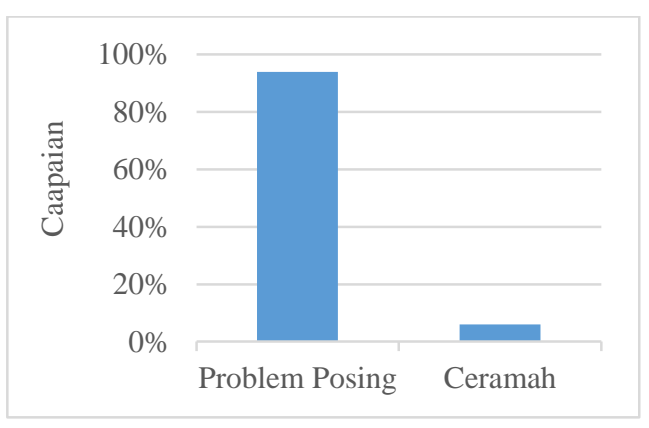

Gambar 6. Penggunaan Metode Pembelajaran Setelah Dilakukan Sosialisasi

Gambar 3 menunjukkan presentase guru dalam menggunakan metode pembelajaran setelah dilakukan sosialisasi menujukkan $94 \%$ yang menggunakan model Problem Posing dan ada 6\% yang masih menggunakan metode ceramah dan belum menggunakan model Problem Posing. Hal ini dikarenakan sebanyak $6 \%$ guru menyatakan masih dalam tahap menyiapkan rancangan pembelajaran yang lebih mantap dan memilih media pembelajaran.

Hasil data untuk pemahaman sintak juga diperoleh dari angket yang 
telah diisi oleh guru dan diperoleh 94\% paham sintak model pembelajaran Problem Posing. Ini menjunjukkan bahwa kegiatan sosialisasi bermanfaat dan diterima oleh para guru untuk digunakan dalam pembelajaran. Berikut pemahaman sintaks model pembelajaran dan guru setelah dilakukan sosialiasi.

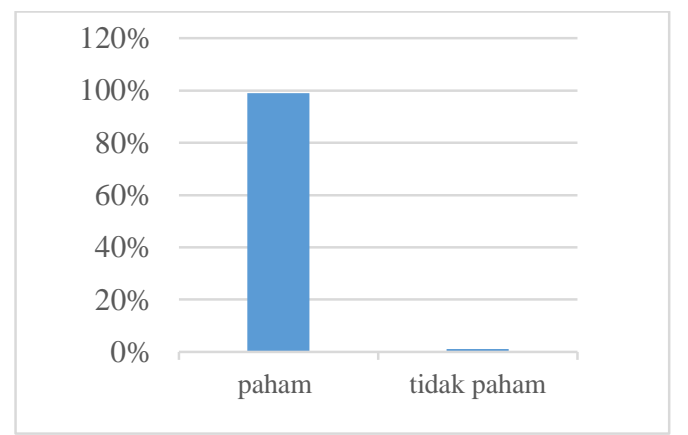

Gambar 7. Pemahaman Guru terhadap Sintaks Model Pembelajaran Sebelum Sosialisasi

Berdasarkan gambar 4 maka diketahui ada 99\% guru sudah paham sintak model pembelajaran Problem Posing setelah dialakukan sosialiasi. Sebanyak $1 \%$ guru yang belum memahami dikarenakan pada saat sosialiasi mengalamai kendala yakni kurang disiplin dalam menyiapkan perangkat pembelajaran.

Bukan hanya guru antusias menggunakan model pembelajaran Problem Posing dan pemahamn sintak oleh guru. Namun adanya pelaksanan sosialisasi menunjukkan hasil bahwa didapatkan 99\% partisipan yakin model pembelajaran Problem Posing dapat meningkatkan daya kritis dan kerativitas. Alasannya sebagai berikut.

a. Model Problem Posing dapat memfasilitasi siswa dalam mengajukan permasalahan berdasarkan materi yang disampaikan guru dan berdasarkan pengalaman yang dimiliki siswa.

b. Melalui model pembelajaran Problem Posing siswa dilatih untuk menemukan masalah, mengajukan masalah, dan memberikan solusi serta pemecahan masalah secara mandiri.

c. Melalui model pembelajaran Problem Posing kemampuan berpikir kritis anak dapat terbangun dan saling menghargai antar teman.

d. Adaya model pembelajaran maka pelaksanaan proses belajar menjadi lebih terarah.

e. Siswa menjadi kreatif dalam membuat pertanyaan dan memecahkan masalah.

Kendati demikian ada kritik dan saran yang disampaikan oleh guru yaitu model pembelajaran Problem Posing bahwa waktu kegiatan pembelajaran harus diperpanjang agar siswa lebih banyak mendapatkan pemahaman yang lebih. Namun disadari oleh guru-guru di MTs Al-Fattah Karungan model 
pembelajaran Problem Posing menjadi model pembelajaran yang dapat menarik guru-guru untuk menerapkan dalam pembelajaran. Sebelum sosialisasi banyak tidak paham mengenai model pembelajaran, namun kini setelah kegiatan sosialisasi para guru di MTs menjadi paham dan tertarik untuk lebih memahami, menerapkan, dan bahkan ingin meneliti yang berkaitan dengan model pembelajaran tersebut. tim peneliti mendapatkan hasil dan refleksi dari sosialisasi mengindikasikan bahwa para guru sebagai partisipan mudah mengingat dan memahami model pembelajaran Problem Posing. Partisipan berpendapat model tersebut dapat meningkatkan motivasi belajar, daya kritis dan kerativitas siswa. Bahkan lebih jauh dari itu dapat menjadikan siswa mandiri, jujur, dan kerja keras. Guru antusias ingin menerapkan model pembelajaran Problem Posing dan menelitinya.

\section{KESIMPULAN}

Adaya pelaksanaan kegiatan yang telah berlangsung maka penerapan model pembelajaran Problem Posing di sekolah banyak manfaatnya bagi guru dan siswa. Guru menjadi lebih memahami tujuan utama Program
Kemitraan Masyarakat (PKM) dengan topik model pembelajaran Problem Posing. Sebagian besar guru menjadi mampu untuk memahami pentingnya penerapan model pembelajaran yang dapat meningkatkan daya pikir dan kreativitas siswa. Selain itu, minat siswa dalam pembelajaran meningkat dan mampu dengan mudah menyerap materi yang disampaikan guru. Dampaknya hasil belajar siswa menjadi meningkat dengan kemampuan siswa yang selalu berpikir kritis dan memiliki daya kreativitas. Ini sangat penting bagi siswa sebagai generasi muda untuk mempersiapkan diri dengan keterampilan yang dibutuhkan oleh organisasi, keluarga, masayarakat, dan negara.

\section{DAFTAR PUSTAKA}

Cai, Jinfa, and Chunlian Jiang. 2017. "An Analysis of Problem-Posing Tasks in Chinese and US Elementary Mathematics Textbooks." International Journal of Science and Mathematics Education 15(8):1521-40. doi: 10.1007/s10763-016-9758-2.

ÇALIK, Fehmi, İsmail ÇELİK, and Selami SÖNMEZ. 2018. "The Investigation of Competence of Teachers and Kindergartens in Terms of Movement Education Achievements in Pre-School Education Program." Journal of Education and E-Learning Research 5(3):179-84. doi: 
10.20448/journal.509.2018.53.179. 184.

Christidamayani, Agatha Puri, and Yosep Dwi Kristanto. 2020. "The Effects of Problem Posing Learning Model on Students' Learning Achievement and Motivation." Indonesian Journal on Learning and Advanced Education (IJOLAE) 2(2):100-108. doi: 10.23917/ijolae.v2i2.9981.

Facione, A. P. 1990. Critical Thinking: A Statement of Expert Consensus for Purposes of Educational Assessment and Instruction. Millbrae, CA: The California Academic Press.

Ikhwani, Yusri, Haldi Budiman, and Muhammad Rasyidan. 2015. "Pelatihan Aplikasi Microsoft Word 2013 Pada SMP H. A. Johansyah. A Banjarmasin." Jurnal Al-Ikhlas 1(1):11-14.

Kartika Irawati, Ratna. 2014. "Pengaruh Model Problem Solving Dan
Problem Posing Serta Kemampuan Awal Terhadap Hasil Belajar Siswa." Jurnal Pendidikan Sains 2(4):184-92. doi: 10.17977/jps.v2i4.4534.

Latif, Nurul Ezhawati Abdul, Faizal Mohamed Yusuf, Nurazrin Mat Tarmezi, Siti Zalika Rosly, and Zairul Nurshazana Zainuddin. 2019. "The Application of Critical Thinking in Accounting Education: A Literature Review." International Journal of Higher Education 8(3):57-62. doi: 10.5430/ijhe.v8n3p57.

Rendi, Jainal Arifin, Firda Herlina, Sobar Ihsan, Budi Hartadi, and dan Gusti Rusdy Furqon Syahrillah. 2020. "Meningkatkan Keterampilan Guru SMK Menggunakan Aplikasi CADSMK Islam Sabilal Muhtadin." Journal of Chemical Information and Modeling 6(1):31-36. 